\title{
ANALISIS MODEL ALTMAN, TAFFLER, DAN ZMIJEWSKI DALAM MEMPREDIKSI PERUSAHAAN YANG DELISTING SECARA PAKSA KARENA KEGAGALAN KEUANGAN DARI BURSA EFEK INDONESIA PERIODE 2010-2014
}

\author{
Meilinda Dwi Anugrah \\ Fakultas Ilmu Sosial dan Humaniora \\ Program Studi Akuntansi Universitas \\ Putera Batam. Kepulauan Riau, \\ Indonesia. \\ E-mail: Meilinda.Dwi@puterabatam.ac.id
}

\begin{abstract}
Abstrak
Penelitian ini bertujuan untuk menguji dan membuktikan apakah model analisis kebangkrutan Altman (1983), Taffler (1983), dan Zmijewski (1984) mampu memprediksi perusahaan yang delisting secara paksa karena kegagalan keuangan dari Bursa Efek Indonesia serta menganalisis tingkat akurasi ketiga model tersebut. Prediksi kebangkrutan dibutuhkan sebagai model untuk mencegah terjadinya kebangkrutan perusahaan yang dapat diantisipasi sejak dini. Sampel penelitian adalah seluruh perusahaan yang dihapuskan pencatatannya secara paksa (delisting) karena kegagalan keuangan. Data yang digunakan adalah laporan keuangan selama tiga tahun sebelum perusahaan mengalami delisting. Penelitian ini dilakukan pada periode 2010 hingga 2014. Berdasarkan hasil uji chi-square masing-masing model prediksi, model Altman (1983) dan Taffler (1983) menunjukkan hasil yang signifikan untuk memprediksi perusahaan yang delisting secara paksa karena kegagalan keuangan selama tiga tahun berturut-turut. Sementara model Zmijewski (1984) memiliki kemampuan yang rendah dalam memprediksi perusahaan yang mengalami delisting secara paksa karena kegagalan keuangan di bursa selama tiga tahun sebelum perusahaan mengalami delisting.
\end{abstract}

Kata kunci: delisting, model prediksi kebangkrutan, Altman, Taffler, Zmijewski.

\section{Latar Belakang}

Menurut Hanafi dan Halim (2009), informasi kebangkrutan bermanfaat bagi banyak pihak diantaranya yaitu; pemberi pinjaman, investor, pihak pemerintah, akuntan dan manajemen. Kebangkrutan atau kegagalan keuangan terjadi ketika suatu perusahaan tidak mampu untuk memenuhi kewajibannya hingga jatuh tempo atau ketika jumlah kewajiban melebihi nilai wajar aset (Elmabrok et al. 2012). Salah satu dampak dari kegagalan keuangan di Bursa Efek Indonesia adalah terjadinya penghapusan secara paksa (delisting) dari bursa. Menurut Peraturan Bursa Efek Nomor I-I Tahun 2014, bursa menghapus pencatatan saham atas perusahaan tercatat karena mengalami masalah kegagalan keuangan (financial distress) atau masalah hukum. Delisting dari daftar efek di bursa terjadi atas kemauan perusahaan tercatat yang bersangkutan atau dihapus secara paksa oleh bursa sesuai dengan peraturan. Delisting karena kemauan dari perusahaan yang bersangkutan biasanya karena ingin melakukan merger atau privatisasi. Sedangkan delisting secara paksa oleh bursa dikarenakan memiliki masalah finansial atau hukum yang berpengaruh negatif terhadap kelangsungan hidup perusahaan tercatat. Prediksi dan pencegahan kegagalan keuangan merupakan salah satu faktor utama yang harus dianalisis untuk memperoleh peringatan awal terjadinya 
kebangkrutan tersebut (Kasilingam \& Ramasundaram, 2012). Terdapat beberapa model prediksi yang populer untuk digunakan dalam menganalisis kebangkrutan perusahaan, diantaranya yaitu: Beaver (1966), Altman (1968), Ohlson (1980), Fulmer (1984). Selain model tersebut, terdapat model lain yang juga dapat memprediksi kebangkrutan perusahaan. Diantaranya yaitu model Taffler (1983) dan Zmijewski (1984). Penelitian terdahulu terbatas pada pengujian model Altman (1968), namun belum ada yang menguji tingkat akurasi model pembaharuan Altman (1983) dan membandingkan tingkat akurasinya dengan model lain. Oleh karena itu, penelitian ini memperluas studi sebelumnya dengan menganalisis tingkat akurasi model prediksi kebangkrutan Altman (1983) dan membandingkan model tersebut dengan model lainnya.

\section{Kajian Teori Dan Pengembangan Hipotesis}

Analisis Kebangkrutan

Berikut tahapan kebangkrutan yang dialami oleh beberapa perusahaan (Kordestani et al. 2011): (1) Latency stage (perusahaan akan mengalami penurunan Return On Assets (ROA); (2)
Shortage of Cash stage (perusahaan tidak memililki sumber daya kas yang cukup untuk memenuhi kewajibannya walaupun masih memiliki tingkat profitabilitas yang tinggi; (3) Financial distresss stage (perusahaan akan mengalami kesulitan keuangan yang darurat (3) Bankruptcy stage (perusahaan tidak mampu untuk mengatasi kesulitan keuangan, sehingga mengakibatkan perusahaan tidak dapat memenuhi kewajiban dan kemudian mengalami kebangkrutan)

\section{Model Altman (1983)}

Model ini dikembangkan oleh Edward I Altman pada 1968. Altman sukses dalam memprediksi kebangkrutan perusahaan dengan menggunakan multiple discriminant analysis dengan tingkat akurasi mencapai 95\%. Altman menggunakan lima rasio keuangan untuk mengukur likuiditas, profitabilitas, financial leverage, aktivitas, dan solvensi. Pada 1983, Altman merevisi ulang model tersebut dengan mengganti variabel $\mathrm{X} 4$ menjadi nilai buku ekuitas per total kewajiban agar dapat di aplikasikan pada perusahaan manufaktur privat (Khoury \& Beaino,

2014).

$$
\mathrm{Z}=0,717 \mathrm{X} 1+0,842 \mathrm{X} 2+3,107 \mathrm{X} 3+0,42 \mathrm{X} 4+0,998 \mathrm{X} 5
$$

Keterangan:

$\mathrm{X} 1=$ Modal kerja per total aset

$\mathrm{X} 2$ = Laba ditahan per total aset

$\mathrm{X} 3$ = Pendapatan sebelum bunga dan pajak per total aset

$\mathrm{X} 4=$ nilai buku ekuitas per total kewajiban

$\mathrm{X} 5=$ Penjualan per total aset

Nilai pisah batas model Altman (1983):

Jika $Z>2,9 \quad$ : Perusahaan tidak dalam kondisi delisting

Jika $Z<1,23 \quad$ : Mengalami delisting

Jika $1,23<\mathrm{Z}<2,9$ : Daerah rawan delisting

Model Taffler (1983)

Model ini dikembangkan oleh R.J Taffler pada 1983. Model Taffler (1983) menggunakan empat variabel dan nilai pisah batas untuk model ini tidak terdapat grey zone. 


$$
\mathrm{ZT}=3,2+12,18 \mathrm{~T} 1+2,5 \mathrm{~T} 2-10,68 \mathrm{~T} 3+0,029 \mathrm{~T} 4
$$

Keterangan:

$\mathrm{T} 1$ = Laba sebelum pajak per kewajiban lancar

$\mathrm{T} 2=$ Aset lancar per total kewajiban

$\mathrm{T} 3=$ Kewajiban lancar per total aset

$\mathrm{T} 4=($ Aset cepat - kewajiban lancar $)$ per $\{$ (penjualan - laba sebelum pajak depresiasi) \} / 365

Nilai pisah batas model Taffler (1983):

Jika $Z>0$ : Perusahaan tidak dalam kondisi delisting

Jika $Z<0 \quad$ : Mengalami delisting

Model Zmijewski (1984)

Model ini dikembangkan oleh Mark E. Zmijewski pada tahun 1984 untuk mengukur kinerja perusahaan, solvabilitas atau leverage, dan likuiditas perusahaan. Berikut model Zmijewski (1984):

$$
\mathrm{Z}=-4,3-4,5 \mathrm{Z} 1+5,7 \mathrm{Z} 2-0,004 \mathrm{Z3}
$$

Keterangan:

$\mathrm{Z} 1$ = Laba bersih per total aset

$\mathrm{Z} 2$ = Total utang per total aset

Z3 = Aset lancar per kewajiban lancar

Nilai pisah batas model Zmijewski (1984):

Jika $Z>/=0,5$ : Diprediksi delisting

Jika $Z<0,5$ : Diprediksi tidak delisting

Hasil penelitian terdahulu menyatakan bahwa model prediksi Beaver (1966) memiliki tingkat akurasi sebesar $90 \%$ dalam mengidentifikasi kebangkrutan perusahaan selama satu tahun sebelum perusahaan bangkrut. Altman (1968) melakukan pengembangan model analisis dari Beaver (1966) dengan mengunakan multiple discriminant analysis (MDA). Hasil dari penelitiannya menunjukkan bahwa tingkat akurasi mencapai $95 \%$ setahun sebelum perusahaan tersebut bangkrut dan $72 \%$ untuk periode dua tahun sebelum bangkrut. Hasil penelitian model Ohlson (1980) menunjukkan tingkat akurasi sebesar 98\% selama satu tahun sebelum perusahaan tersebut mengalami kebangkrutan dan $81 \%$ setelah lebih dari satu tahun mengalami kebangkrutan. Hasil dari penelitian Hartanti (2011) menunjukkan bahwa tingkat akurasi model Altman dapat memprediksi perusahaan yang delisting sebesar 78,57\% dan akurasi model Wang dan Campbell dapat memprediksi 32,14\%. Tetapi, penelitian Hartanti tidak membedakan antara perusahaan yang delisting secara paksa karena kegagalan keuangan maupun secara sukarela. Raras (2014) menggunakan model analisis Altman (1983), Wang dan Campbell (2010), serta Springate (1978). Hasil dari penelitian menunjukkan bahwa akurasi model Altman lebih dari $92 \%$ dapat memprediksi perusahaan yang delisting dari bursa efek, kemudian Springate dengan tingkat akurasi 90\%, dan Wang dan Campbell dapat memprediksi sebesar 89,5\%. Pada penelitian ini, Raras (2014) melakukan perbaikan dalam penelitian yang dilakukan Hartanti (2011), yaitu dengan membedakan perusahaan yang delisting secara paksa karena kegagalan keuangan maupun secara sukarela.

Berdasarkan uraian diatas dan penelitian terdahulu mengenai model prediksi kebangkrutan, maka hipotesis yang diambil adalah:

H1: Model Altman (1983) татри memprediksi perusahaan yang 
delisting secara paksa karena kegagalan keuangan dari pencatatan Bursa Efek Indonesia.

H2: Model Taffler (1983) татри memprediksi perusahaan yang delisting secara paksa karena kegagalan keuangan dari pencatatan Bursa Efek Indonesia.

H3: Model Zmijewski (1984) mampu memprediksi perusahaan yang delisting secara paksa karena kegagalan keuangan dari pencatatan Bursa Efek Indonesia.

\section{Metode Penelitian}

Populasi dalam penelitian ini adalah perusahaan yang masih listing dan perusahaan yang dinyatakan delisting oleh Bursa Efek Indonesia (BEI) pada tahun 2010 hingga 2014. Sampel yang diambil dalam populasi ini dibagi menjadi dua kelompok, yaitu kelompok satu untuk emiten yang dinyatakan delisting dan kelompok dua untuk emiten yang masih listing. Penelitian ini menggunakan data selama tiga tahun sebelum perusahaan mengalami delisting. Pengambilan sampel dilakukan dengan metode purposive sampling. Kriteria untuk kelompok delisting adalah perusahaan yang dinyatakan delisting secara paksa karena kegagalan keuangan di BEI pada tahun 2010 hingga 2014, perusahaan tersebut merupakan perusahaan nonkeuangan dan bukan perusahaan yang delisting karena merger atau go private, serta perusahaan tersebut mengeluarkan laporan keuangan yang lengkap. Sampel kelompok listing dibagi menjadi dua yaitu sampel pembanding kecil dan sampel pembanding besar. Perusahaan yang mengalami delisting akan dibandingkan dengan kedua kelompok sampel tersebut. Sampel pembanding kecil adalah perusahaan yang berasal dari industri yang sama dan memiliki nilai aset yang besarnya hampir sama dengan kelompok perusahan delisting, sedangkan sampel pembanding besar berasal dari industri yang sama dengan perusahaan kelompok delisting.

\section{Analisis Dan Pembahasan}

Selama tahun 2010 hingga 2014, terdapat 18 perusahaan yang mengalami delisting dari bursa. Di antara 18 perusahaan yang delisting, hanya 10 perusahaan yang delisting karena kegagalan keuangan. Namun, di antara 10 perusahaan yang mengalami delisting secara paksa karena kegagalan keuangan, hanya 6 perusahaan yang dapat dijadikan sampel. Hal ini dikarenakan 4 perusahaan lainnya tidak memenuhi kriteria pengambilan sampel, yaitu tidak menerbitkan laporan keuangan satu tahun sebelum perusahaan tersebut delisting. Sampel untuk perusahaan listing dibagi menjadi dua yaitu sampel pembanding kecil dan sampel pembanding besar. Berikut jumlah sampel yang digunakan dalam penelitian ini:

Tabel 1 Sampel pembanding kecil

\begin{tabular}{|l|c|}
\hline $\begin{array}{l}\text { Jumlah perusahaan yang delisting secara paksa karena kegagalan keuangan } \\
\text { dengan data laporan keuangan lengkap }\end{array}$ & 6 \\
\hline $\begin{array}{l}\text { Jumlah perusahaan pembanding dari industri yang sama dan memiliki nilai } \\
\text { aset yang mendekati }\end{array}$ & 6 \\
\hline
\end{tabular}

Tabel 2 Sampel pembanding besar

\begin{tabular}{|l|c|}
\hline $\begin{array}{l}\text { Jumlah perusahaan yang delisting secara paksa karena kegagalan keuangan } \\
\text { dengan laporan keuangan lengkap }\end{array}$ & 6 \\
\hline Jumlah perusahaan pembanding dari industri yang sama & 116 \\
\hline
\end{tabular}




\section{Hasil uji Chi-Square}

Uji Chi-Square model Altman (1983)

Altman (1983) membagi z-score kedalam 3 kategori, yaitu delisting, rawan, dan listing. Dalam penelitian ini, kategori rawan digabung menjadi satu dalam kategori listing karena perusahaan dengan prediksi rawan pada kenyataannya masih listing di bursa.

Tabel 3 Hasil pengujian Chi-Square sampel pembanding kecil dengan model Altman (1983)

\begin{tabular}{|c|r|r|}
\hline Model Altman & Chi-Square & p value \\
\hline $\mathrm{t}-1$ & 6,000 & $0,050^{*}$ \\
\hline $\mathrm{t}-2$ & 6,000 & $0,050^{*}$ \\
\hline $\mathrm{t}-3$ & 4,500 & 0,105 \\
\hline
\end{tabular}

Berdasarkan hasil uji chi-square dengan model Altman (1983) yang disajikan pada tabel 3, tahun pertama dan kedua sebelum delisting menunjukkan angka 6,000, atau lebih besar dari chisquare tabel yaitu 5,991. Ini artinya, model Altman (1983) signifikan. Namun pada tahun ketiga sebelum delisting model Altman (1983) tidak signifikan karena nilai chi-square lebih kecil dari chi-square tabel. Pada tahun pertama dan kedua sebelum delisting, $p$ value menunjukkan angka yang signifikan. Sedangkan tahun ketiga sebelum delisting menunjukkan angka yang tidak signifikan. Angka $p$ value dianggap signifikan jika angka tersebut lebih kecil dari tingkat signifikansi, yaitu lebih kecil dari 5\% atau 0,005. Berikut hasil pengujian chi-square dengan model Altman (1983) untuk sampel pembanding besar:

Tabel 4 Hasil pengujian Chi-Square sampel pembanding besar dengan model Altman (1983)

\begin{tabular}{|c|r|r|}
\hline Model Altman & Chi-Square & $p$ value \\
\hline $\mathrm{t}-1$ & 10,426 & $0,005^{*}$ \\
\hline $\mathrm{t}-2$ & 6,752 & $0,034^{*}$ \\
\hline $\mathrm{t}-3$ & 6,025 & $0,049^{*}$ \\
\hline
\end{tabular}

Hasil uji chi-square sampel pembanding besar pada tabel 4 menunjukkan hasil yang signifikan selama 3 tahun berturut-turut sebelum delisting, yaitu sebesar 10,426; 5,752; dan 6,025 . Selain itu, nilai $p$ value untuk tahun pertama hingga tahun ketiga juga menunjukkan hasil signifikan, yaitu sebesar 0,005; 0,034; dan 0,049.

\section{Uji Chi-Square model Taffler (1983)}

Kategori perusahaan dibedakan menjadi dua, yaitu delisting dan listing. Berikut hasil analisis uji chi-square dengan model Taffler (1983) pada sampel pembanding kecil:

Tabel 5 Hasil pengujian Chi-Square sampel pembanding kecil dengan model Taffler (1983)

\begin{tabular}{|c|r|r|}
\hline Model Taffler & Chi-Square & p value \\
\hline $\mathrm{t}-1$ & 6,000 & $0,014 *$ \\
\hline $\mathrm{t}-2$ & 1,500 & 0,221 \\
\hline $\mathrm{t}-3$ & 0,000 & 1,000 \\
\hline
\end{tabular}

Tabel 5 menunjukkan bahwa hasil uji chi-square sampel pembanding kecil pada tahun pertama adalah signfikan karena chi-square hitung lebih besar dari chi-square tabel, yaitu 3,841. Sementara tahun kedua dan ketiga tidak menunjukkan hasil yang signifikan. Selain itu, nilai $p$ value selama tiga tahun sebelum delisting adalah 0,$014 ; 0,221$; dan 1,000. Hasil ini menunjukkan bahwa hanya pada tahun pertama model Taffler (1983) menunjukkan angka signifikan. Sementara untuk tahun kedua dan ketiga tidak menunjukkan angka signifikan. Berikut hasil pengujian chi-square dengan model Taffler (1983) pada sampel pembanding besar:

Tabel 6 Hasil pengujian Chi-Square sampel pembanding besar dengan model Taffler (1983)

\begin{tabular}{|c|r|r|}
\hline Model Taffler & Chi-Square & $p$ value \\
\hline $\mathrm{t}-1$ & 21,185 & $0,000^{*}$ \\
\hline $\mathrm{t}-2$ & 6,233 & $0,013^{*}$ \\
\hline $\mathrm{t}-3$ & 3,673 & 0,055 \\
\hline
\end{tabular}


Berdasarkan hasil uji chi-square yang disajikan pada table 6, sampel pembanding besar menunjukkan hasil yang signifikan selama 3 tahun berturutturut. Selain itu, nilai $p$ value untuk tahun pertama dan kedua menunjukkan angka yang signifikan pada batasan $5 \%$. Sedangkan tahun ketiga menunjukkan angka signifikan pada batasan $10 \%$.

\section{Uji Chi-Square model Zmijewski (1984)}

Berikut hasil analisis uji chi-square model Zmijewski (1984) pada sampel pembanding kecil:

Tabel 7 Hasil pengujian Chi-Square sampel pembanding kecil dengan model Zmijewski (1984)

\begin{tabular}{|c|r|r|}
\hline Model Zmijewski & Chi-Square & $p$ value \\
\hline $\mathrm{t}-1$ & 0,000 & 1,000 \\
\hline $\mathrm{t}-2$ & 0,000 & 1,000 \\
\hline $\mathrm{t}-3$ & 1,333 & 0,248 \\
\hline
\end{tabular}

Hasil uji chi-square sampel pembanding kecil pada tabel 7 menunjukkan bahwa selama 3 tahun berturut-turut model Zmijewski (1984) menunjukkan hasil yang tidak signifikan. Selain itu, nilai $p$ value selama 3 tahun berturut-turut berada dibawah tingkat signifikansi.

Tabel 8 Hasil pengujian Chi-Square sampel pembanding besar dengan model Zmijewski (1984)

\begin{tabular}{|c|r|r|}
\hline $\begin{array}{c}\text { Model } \\
\text { Zmijewski }\end{array}$ & $\begin{array}{c}\text { Chi- } \\
\text { Square }\end{array}$ & p value \\
\hline $\mathrm{t}-1$ & 0,797 & 0,372 \\
\hline $\mathrm{t}-2$ & 7,384 & $0,007^{* *}$ \\
\hline $\mathrm{t}-3$ & 2,968 & 0,085 \\
\hline
\end{tabular}

Hasil uji chi-square sampel pembanding besar pada tabel 8 selama 3 tahun berturut-turut adalah 0,797; 7,384; dan 2,968. Model Zmijewski (1984) menunjukkan hasil yang signifikan pada tahun kedua dan ketiga. Pada tahun kedua nilai $p$ value menunjukkan angka signifikan dengan batasan $1 \%$ dan tahun ketiga signifikan dengan batasan $10 \%$.
Berdasarkan hasil analisis uji chi-square di atas, dari ketiga model yang dapat memberi hasil signifikan selama tiga tahun berturut-turut adalah model Altman (1983) dan Taffler (1983). Sementara model Zmijewski (1984) memiliki tingkat signifikansi rendah. Pada sampel pembanding kecil, model Altman (1983) memberikan hasil yang signifikan untuk tahun pertama dan kedua sebelum delisting. Model Taffler (1983) memberikan hasil yang signifikan hanya pada tahun pertama sebelum delisting. Model Zmijewski (1984) tidak memberikan hasil yang signifikan selama tiga tahun berturut-turut sebelum delisting. Pada sampel pembanding besar, model Altman (1983) dan model Taffler (1983) menunjukkan hasil yang signifikan selama tiga tahun berturut-turut sebelum delisting. Sementara model Zmijewski (1984) menunjukkan hasil yang signifikan pada tahun kedua dan ketiga sebelum delisting.

Tabel 9 Tingkat Akurasi Sampel Pembanding Kecil

\begin{tabular}{|c|c|c|c|}
\hline & $\begin{array}{c}\text { Altman } \\
(1983)\end{array}$ & $\begin{array}{c}\text { Taffler } \\
(1983)\end{array}$ & $\begin{array}{c}\text { Zmijewski } \\
(1984)\end{array}$ \\
\hline t-1 & $83,3 \%$ & $83,35 \%$ & $50 \%$ \\
\hline t-2 & $83,3 \%$ & $66,65 \%$ & $50 \%$ \\
\hline t-3 & $66,65 \%$ & $50 \%$ & $33,3 \%$ \\
\hline
\end{tabular}

Sedangkan pada sampel pembanding besar yang disajikan pada tabel 9, tingkat akurasi paling tinggi pada tahun pertama dihasilkan dari model Taffler (1983), lalu posisi kedua adalah model Altman (1983), dan terakhir model Zmijewksi (1984). Pada tahun kedua dan ketiga, tingkat akurasi yang paling tinggi adalah model Altman (1983), lalu posisi kedua model Taffler (1983), dan terakhir adalah model Zmijewski (1984). 
Tabel 10 Tingkat Akurasi Sampel Pembanding Besar

\begin{tabular}{|c|c|c|c|}
\hline & $\begin{array}{c}\text { Altman } \\
(1983)\end{array}$ & $\begin{array}{c}\text { Taffler } \\
(1983)\end{array}$ & $\begin{array}{c}\text { Zmijewski } \\
(1984)\end{array}$ \\
\hline t-1 & $82,75 \%$ & $90,5 \%$ & $54,9 \%$ \\
\hline t-2 & $75,25 \%$ & $68,55 \%$ & $64,05 \%$ \\
\hline t-3 & $74 \%$ & $65,95 \%$ & $61,05 \%$ \\
\hline
\end{tabular}

Hasil penelitian ini mendukung penelitian sebelumnya (Raras, 2014) dalam sampel pembanding kecil dan sampel pembanding besar yang menunjukkan bahwa Altman (1983) dapat memprediksi perusahaan yang delisting selama 3 tahun berturut-turut. Selanjutnya, penelitian yang dilakukan oleh Taffler (1983) menunjukkan bahwa tingkat akurasi perusahaan yang diprediksi delisting sesuai dengan kenyataannya adalah sebesar $96 \%$, dan perusahaan yang diprediksi listing sesuai dengan kenyatannya adalah sebesar $74 \%$. Marcinkevicius dan Kanapickiene (2014) melakukan penelitian dengan menggunakan model Taffler (1983) selama tiga tahun sebelum delisting dengan jumlah sampel sebanyak 244 perusahaan. Hasil penelitian menunjukkan bahwa model Taffler (1983) memiliki tingkat akurasi rendah. Dari pemaparan di atas, dapat disimpulkan bahwa penelitian ini mendukung penelitian dari Taffler (1983) dan juga Marcinkevicius dan Kanapickiene (2014). Penelitian Grice dan Dugan (2003) menyimpulkan bahwa tingkat akurasi model Zmijewski (1984) untuk perusahaan yang delisting mencapai $58,7 \%$ untuk kelompok delisting dan $86,1 \%$ untuk kelompok listing, dengan total akurasi sebesar 81,3\%. Dibandingkan penelitian sebelumnya, penelitian ini menunjukkan perbedaan, yakni tingkat akurasi yang rendah untuk model Zmijeski (1984).

\section{Kesimpulan}

Berdasarkan hasil uji chi-square, maka dapat disimpulkan bahwa model yang dapat memprediksi perusahaan yang mengalami delisting dengan baik dan memberikan hasil yang signifikan adalah model Altman (1983) dan Taffler (1983). Model Zmijewski (1984) memiliki banyak kesalahan prediksi sehingga tidak menunjukkan hasil yang signifikan. Pada sampel pembanding kecil, tingkat akurasi model Altman (1983) pada tahun pertama dan kedua adalah sebesar 83,3\%, sementara tahun ketiga sebesar $66,65 \%$. Model Taffler (1983) memiliki tingkat akurasi selama tiga tahun berturut-turut sebelum delisting adalah 83,35\%; 66,65\%; dan 50\%. Model Zmijewski (1984) memiliki tingkat akurasi sebesar $50 \%$ untuk tahun pertama dan kedua. Sedangkan pada tahun ketiga model Zmijewski (1984) memberikan tingkat akurasi yang rendah, yaitu sebesar 33,3\%. Pada sampel pembanding besar, model Altman (1983) dan Taffler (1983) memberikan hasil yang signifikan selama tiga tahun berturut-turut sebelum delisting. Sedangkan model Zmijewski (1984) memberikan hasil yang signifikan untuk tahun kedua dan ketiga. Tingkat akurasi model Altman selama tiga tahun berturut- turut sebelum delisting adalah $82,75 \% ; 75,25 \%$ dan $74 \%$. Model Taffler (1983) menghasilkan tingkat akurasi selama tiga tahun berturut-turut adalah 90,5\%; 68,55\%; dan 65,95\%. Model Zmijewski (1984) menghasilkan tingkat akurasi sebesar 54,9\% pada tahun pertama. Kemudian pada tahun kedua dan ketiga menghasilkan tingkat akurasi sebesar $64,05 \%$ dan $61,05 \%$.

Dari penjelasan di atas, dapat disimpulkan bahwa model pertama yang paling baik dalam memprediksi perusahaan yang delisting dari bursa adalah model Altman (1983), lalu Taffler (1983) dan terakhir adalah model Zmijewski (1984). Penelitian memiliki beberapa keterbatasan, yaitu tidak lengkapnya data laporan keuangan dari beberapa perusahaan saat satu tahun sebelum perusahaan tersebut delisting, sehingga jumlah sampel perusahaan delisting dari tahun 2010 hingga 2014 
yang memiliki laporan keuangan lengkap sedikit.

\section{DAFTAR PUSTAKA}

Achim, V. M., \& Borlea, N. S. (2012). Consideration on Business Risk of Bankruptcy. Faculty of Economics and Business Administration \& Faculty of Science Economics, Romania.

Altman, E. I. (1968). Financial Ratios, Discriminant Analysis and the Prediction of Corporate Bankruptcy. Journal of Finance, 23(4), 589-609. New York: John Wiley.

Altman, E. I. (1983). Corporate Financial Distress: A complete guide to predicting $\&$ distress and profiting from bankruptcy. ( $2^{\text {nd }}$ ed.). New York: John Wiley.

Beaver. W. (1966). Financial Ratios as Prediction of Failure. Journal of Accounting Research 4, 71-111.

Elmabrok, A. A. (2012). Using Altman's Model and Current Ratio to Asses the Financial Status of Companies Quoted in the Malaysian Stock Exchange. International Journal of Scientific and Research Publications 2.

Fulmer, J. G. Jr., Moon, James E., Gavin, Thomas A., Erwin, Michael J. (1984) A Bankruptcy Classification Model For Small Firms. Journal of Commercial Bank Lending, 25-37.

Grice, J. T \& Dugan, M. T. (2001). The Limitations of Bankruptcy Prediction Models: Some Cautions for the Researcher. Review of Ouantitavie Finance and Accounting, 17, 151-166.

Grice, J. T \& Dugan, M. T. (2003). ReEstimation Of The Zmijewski and Ohlson Bankruptcy Prediction Models. Advanced in Accounting 20,77-93. Elsevier.

Hanafi, M. M \& Halim, A. (2009). Analisis Laporan Keuangan.Yogyakarta: UPP STIM YKPN.
Hartanti, V. (2011). Analisis Ketepatan Model Kebangkrutan Dalam Memprediksi Perusahaan Yang Delisting Dari Bursa Efek Indonesia. Yogyakarta, Indonesia: EBDL.

Ohlson. J. (1960). Financial Ratios and the Probabilistic of Bankruptcy. Journal of Accounting Research 18, 109-131.

Kasilingam, R. \& Ramasundaram, G. (2012). Predicting Solvency of Non -Banking Financial Institution In India Using Fulmer and Springate Model. Journal of Services Research, 12(1), April-September 2012.

Khoury, E., Beaino, A. (2014). Classifying Manufacturing Firms in Lebanon: An Application of Altman's Model. Procedia-Social and Behavioral Sciences 109, 11-18. Elsevier.

Kordestani, G., Biglari, V., \& Bakhtiari, M. (2011). Ability of Combination of Cash Flow Components to Predict Financial Distress. Business: Theory and Practice, 12(3), 277285.

Marcinkevicius, R., \& Kanapickiene, R. (2014). Bankruptcy Prediction in the Sector of Construction in Lithuania. Procedia-Social and Behavioral Sciences 156, 553-557. Elsevier.

Raras, D. (2014). Analisa Prediksi Kegagalan Keuangan Model Altman, Wang Campbell, Springate yang delisting tahun 2009-2012.

Taffler, R. J. (1983). The Assesment of Company Solvency and Performance Using a Statistical Model. Accounting and Business Research, 13:52, 295-308.

Zmijewski, M. E. (1984). "Methodological Issues Related to the Estimation of Financial Distress Prediction Models."Journal of Acoounting Research 22, 59-82. 